\title{
Petr Bělovský
}

\section{OWNERSHIP AND PROPERTY IN COMMUNIST CIVIL CODES OF CZECHOSLOVAKIA}

\begin{abstract}
The distribution of property in society is a fundament of communist ideology, which in Czechoslovakia was regulated by two Civil Codes. In the process of reforming the entire legal system, the purpose of both codes was, besides property regulation, also to transform the perception of the importance of ownership in society and to change the way people think about the role of property. In order to achieve this, the communist legislation introduced brand new property-rights institutions, which were supposed to replace ownership - in particular, the so-called 'use' (uživání) of property. The ultimate goal of the communist property reform, however, became so-called socialist ownership, which corresponded to the requirements of communist ideology and which existed in public and individual form.

This article presents the various types of ownership regulated in the Czechoslovak Civil Codes in the years 1948-1989. It also draws attention to some of the pitfalls of applying different forms of property in legal practice, particularly as regards land. It also points out the difference between the political demands placed on property law legislation and the economic reality of the day, which, among other things, contributed to the gradual weakening of the confidence in the Communist Party of Czechoslovakia and eventually led to the fall of the whole regime.
\end{abstract}

* Petr Bělovský, assistant professor, Department of Legal History, Faculty of Law, Univerzita Karlova, Praha, email address: belovsky@prf.cuni.cz. ORCID: 0000-0002-0774-3347. 
Keywords: communism, ownership, property, socialist property, civil code, Czechoslovakia

Ownership of the means of production as well as consumer goods is one of the key issues of communist ideology, which aims to build a centralised economic system that would enable a new model of the social and economic order. The social role of property and ownership was seen by Marxist-Leninist ideology as one of the main elements in the process of transforming the capitalist society into a socialist and subsequently a communist society. The role of law has been reduced to a mere tool to achieve these ideologically motivated political-economic goals.

The new legal concept of property law and particularly ownership was, therefore, one of the main characteristics of the law during the communist era in Czechoslovakia. The new understanding of ownership was based on the objectives of the communist movement and the Soviet political and economic model. ${ }^{1}$

The traditional civil law concept of ownership based on Roman law was repeatedly criticised by the communist ideologists due to its individualistic character as well as its close connection to the free-market economy. This was against the collectivistic objective aiming to build a perfectly equal society. Private ownership was seen as a result of a broader concept of private law that was introduced by Roman law. Lenin, therefore, stated: 'We do not accept anything which is private. For us is everything which regards the economy always public, never private'2 This is why also the Czechoslovak Civil Codes of 1950 and 1964 were not considered codes of private law, on the contrary, one of the main objectives of these civil codes was to eliminate the traditional distinction between private and public law since all communist law was officially regarded as public law. ${ }^{3}$

The new socialist society was, therefore, to be built on the new principles by limiting individual ownership and reshaping the society according to the communist doctrine. As for property, this meant, among other things, that the

Knapp, V., Vlastnictví v lidové demokracii, Praha 1952, p. 9.

2 Lenin, V. I., On the Responsibilities of the People's Commissariat of Justice in Conditions of the New Economic Policy - a letter to the People's Commisariat of Justice. See: Bosiacki, A., Roman Law in Totalitarian Systems: Soviet Union, Italy and Germany - Case Study, in: $A u$ delà frontières, melanges de droit Romain offert à Witold Wolodkiewicz, Warszawa 2000, vol. 1, 131-138.

3 Bělovský, P., Občanské právo, in: Bobek, M., Molek, P., and Šimíček, V. Komunistické právo v Československu: Kapitoly z dějin bezpráví, Brno 2009, pp. 425-462. 
people were to be discouraged from accumulating property and motivated into changing their 'property habits', as it was described by various legal scholars of that time. ${ }^{4}$ This is why in the later period of development of socialist law, especially in the 1960s, the opinion of Soviet specialists, according to which the temporary use of property (in the form of lending or lease) is economically and politically more efficient than ownership, prevailed. Officially, the so-called 'personal use' (osobni užívání) was declared to be a higher economic form of the disposal of property. The General Secretary of the Communist Party of the Soviet Union N. Khrushchev expressed the thought during his meeting with representatives of French syndicates that in order to meet the demand of the people for automobiles, the industry could produce ten times fewer automobiles when lending to people than selling them directly to them. ${ }^{5}$ As a paradox, new free-market economic models of the $21^{\text {st }}$ century follow a similar idea, as seen by the growing demand for property-sharing (cars, bicycles, etc). However, in contrast to the communist ideology, this trend is spontaneous and based on real demand from consumers.

\section{Two Civil Codes}

Shortly after the communist takeover in February 1948, a new Czechoslovak constitution was adopted (already in May 1948), which openly expressed the 'decision to build a people's democracy' and proclaimed the determination to take the path to socialism. As part of the initiated reform of the entire legal order, a new Civil Code was adopted in 1950, based on the recently adopted constitution. The Civil Code of 1950 ('CC1950') was an ideologically influenced statute that, among other things, was supposed to contribute to the process of changing the property habits of the people in order to prepare the ground for socialism. CC1950 was officially proclaimed as 'the people's code', a code for the modern era, while at the same time the Austrian Civil Code (ABGB) that it was to replace was depicted as a symbol of the past.

The subsequent development of the society in the 1950s could be characterised as the conservative period of the communist regime. Inspired by

4 Dvonč, F. and Štěpina, J., Návrh nového občanského zákonnika-zákonníka socialistickej spoločnosti, "Právny obzor" 1963, No. 3, p. 161.

5 Khruschev, N. S., Moskovskaia Pravda, April 2, 1960; Dvonč, F. and Štěpina, J., Návrh..., p. 162. 
the Soviet Union, many people opposing the communist regime were imprisoned or even executed. Most private property was confiscated. As a result, the enthusiasm of the Communist Party supporters for building a state providing equal opportunities for all, typical of the beginning of the 1950s, slowly cooled down with the end of the decade. The improving post-war economy began to stagnate and this resulted in a crisis in the beginning of the 1960s. As a paradox, this happened at a time when, according to the predictions of the communist ideologists, the productivity of industry should have increased five times compared to the beginning of the 1950s and socialism should have been achieved. ${ }^{6}$

Instead of openly facing the economic crisis, the Communist Party decided to proclaim that all the objectives of the socialist economy had been reached, the foundations of socialism constructed and that the next generation of Czechoslovak citizens would live in communism. ${ }^{7}$ Further steps were made in socialist legislation to intensify the ideological contents of the key statutes. Considerable amendments were made to the criminal code and new statutes enforcing the socialist regime were promulgated, namely the statute on the state prosecution and a new statute on the state police. All these changes were based on the new constitution of 1960, which changed the name of the Czechoslovak Republic to the Czechoslovak Socialist Republic and proclaimed the leading role of the Communist Party in state affairs.

Based on the provisions of the new constitution, a new Civil Code was introduced in 1964 ('CC1964'). It was aimed at continuing the transformation process initiated by CC1950 and to make the next step - it was to 'prepare society for a life in communism', which was regarded as the final stage of the transformation process by the communist ideologists. This is why compared to the previous code CC1964 was considerably more radical. With the intention to eliminate what was left of the ABGB in the CC1950, the authors of the new code invented new legal institutes that were to replace the traditional ones. Some of the fundamental civil law institutes derived from the Roman law tradition, such as possession, prescription, servitudes, and to some extent also contracts

6 Barnovský, M., K niektorým otázkam spoločenského vývoja Československa v šest'desiatych rokoch, in: "Dějiny socialistického Československa" 1989, No. 10, p. 16.

7 This was officially declared by Czechoslovak President Antonín Novotný at the meeting of the Soviet Communist Party in 1961. A similar declaration had been expressed already at the meeting of the Czechoslovak Communist Party in 1958. 
(!) were abolished. They were replaced by the ideologically acceptable new institutions named 'personal use' (osobni uživáni - to replace possession and servitudes) and 'services' (služby - to replace contracts). The traditional legal entities were replaced by socialist organisations (socialistické organizace).

The primary task of the new code was to transform the common way of life and to change the way people think about property. Its purpose, therefore, remained the same as with $\mathrm{CC} 1950$, only the process achieving it was intensified, regardless of the fact that the social analysis of the effects of CC1950 on the Czechoslovak population had shown that it had failed in this role. CC1964 contained a preamble openly declaring the main objective to 'lead the society into communism'. Apart from that, it proclaimed the close connection between the law and the state-planned economy and the principal role of the socialist organisations (socialistické organizace) that were established in order to 'meet all the demands of the citizens', but in fact were to strengthen the centralisation of the economy. Officially, every person could enjoy the services provided by the socialist organisations to the extent he or she 'contributed to the process of constructing communism'.

In general, all the contents of CC1964 were built on a utopian vision, ignoring the real situation in society. The mistake of this approach was proven by the freedom movement in 1968, suppressed by an invasion by military troops of the Warszawa pact in August of the same year. This is why CC1964 was significantly amended in 1982. Most of the traditional institutions were reintroduced, namely possession and servitudes. Services, however, remained dominant over contracts. Regardless of these partial changes, the character of the whole law remained the same.

At the time of the fall of the communist regime in 1989, this code was still in effect. One of the main tasks of the democratic legislation was to prepare a new code that would suit the democratic society and the market economy. The intensive need for a new code, however, resulted in 1991 in a temporary solution that brought only an amendment of CC1964. At the same time, the preparation of a whole new code, which was expected to take more time, was initiated in the beginning of the 1990s. However, only in 2012, some 23 years after the fall of the communist regime in Czechoslovakia, was the amended CC1964 replaced by a new civil code that returned to the traditional civil law. 


\section{Types of property ownership in the socialist Civil Codes}

Under the influence of the state ideology, the traditional institutions of property law also obtained new contents. The socialist law treated ownership as a collective institution, emphasizing its economic character: 'Ownership becomes social, it becomes a productive relationship of the people determined by the new economic and social structure on the socialist basis' ${ }^{8}$

The socialist understanding of ownership was derived from the Czechoslovak constitution of 1948 and subsequently from CC1950, which introduced the primary division of ownership into three specific forms: socialist ownership, personal ownership, and private ownership.

\section{Socialist ownership}

Socialist ownership (socialistické vlastnictvi) was a collective form of ownership established as an institution by the intensive process of nationalisation and supported by the centrally planned economy. Socialist ownership became a part of the newly introduced concept of civil law and at the same time a counter-balance to the traditional concept of ownership..$^{9}$ It was proclaimed to be a progressive form of ownership since the traditional Roman law-based type of ownership was not suitable for the socialist society and was also considered obsolete. The legislative commentary to CC1950 presented socialist ownership as the shield against the exploitation of workers and it was to provide 'constant growth of wealth of the workers'.

Socialist ownership should not be, however, understood as equivalent to state ownership. ${ }^{10}$ Apart from state property, the object of socialist ownership was also the property of cooperatives and property in personal ownership that had also a socialist character.

According to the official ideology, property in socialist ownership did not belong to the state but to the workers. In practice, however, it was the state that disposed of so-called socialist state property and this is why the state had pro-

8 The Legislative Commentary to CC1950, intro., art. 7.

9 Venědiktov, A. V., Státní socialistické vlastnictví, Praha 1950, p. 357.

10 Bělovský, P., Instituty občanského práva 1950-1982, in: Kuklík, J. (ed.), Dějiny československého práva 1945-1989, Praha 2011, pp. 352-354; Karass, A. V. Obsah práva státního socialistického vlastnictví, "Sovětskoje gosudarstvo i pravo" 1949, No. 7. 
claimed itself the representative of the working class. The ownership of state property, so-called national property (národni majetek), was exercised by the state either directly (this was state socialist ownership - státní socialistické vlastnictvi) or indirectly using the authorities assigned for the administration of the national and community companies (i.e., the socialist legal persons - socialistické právnické osoby) later called the socialist organisations. ${ }^{11}$ These subjects were entitled to obtain socialist property in order to provide services to the public through so-called 'permanent use' (trvalé uživáni).

In order to ensure that socialist property (i.e., national property) was not used for individual benefit, CC1950 restricted the transfer of socialist ownership. This was to prevent the transfer of socialist property to individuals. The products of socialist industry could be transferred to personal ownership (osobni vlastnictvi) only if they were part of the socialist production designated for personal consumption.

CC1964 continued to distinguish the types of ownership introduced by the constitution of 1948 and CC1950. Unlike CC1950, the 1964 code does not define socialist ownership (it does, however, give a general definition of ownership, see above). It is, however, mentioned by the enacting clause of the code: 'the constantly developing social production based on the property in socialist ownership is the source of meeting the demands of the citizens; every person is obliged to develop, strengthen and protect this property'. Socialist ownership remained part of the Civil Code until the democratic reform of the law after the revolution of 1989.

Technically, the treatment of socialist ownership by both Civil Codes was very poor. There are many unclear provisions that cause considerable confusion about which property may be in socialist ownership and which would be in personal or private ownership. One of the most significant problems was the question of ownership of land.

\section{Socialist ownership of the cooperatives}

A specific form of socialist ownership was the ownership of 'people's cooperatives', or cooperative ownership (družstevni vlastnictvi). ${ }^{12}$ The constitution of

11 Knapp, V. Operativní správa národního majetku národními podniky, in: Knapp, V., Isaakovič Škundin, Z., and Petržalka, K., K otázkám nového občanského práva, Praha 1950, p. 15 ssq.

12 Bělovský, P., Instituty..., pp. 354-356. 
1948 presented a definition of these cooperatives: 'the people's cooperatives are the unions of the workers associated for the purpose of a common activity aimed to increase the living standard of its members and all the working people, but not to achieve the highest possible profit from the invested capital'. ${ }^{13}$ The ownership of land other than 'people's cooperatives' was not considered socialist ownership. This regarded particularly the so-called 'private-capital cooperatives' that had operated on the territory of Czechoslovakia since the 1920s. However, in the beginning of the process of the socialist transformation, even the people's cooperatives did not meet the standards required by the Communist Party and the socialist jurisprudence. The proper socialist cooperatives as defined by the constitution were to be established later with the achievement of a higher level of nationalisation and collectivisation. ${ }^{14}$

Cooperative ownership was thus regarded as a form of collective ownership, in the same way as state ownership (unlike personal and private ownership). Cooperative ownership was nevertheless considered to be a kind of ownership inferior to state ownership. On the scale of the ownership hierarchy, it was therefore placed between state and private ownership and it was this position that determined its limits. In practice, this meant that property capable of being exclusively the object of state ownership was excluded from cooperative ownership, while property capable of being in private ownership was also capable of being in the ownership of the cooperatives.

CC1964 followed the concept of CC1950 regarding cooperative ownership. However, at the time when CC1964 came into effect, the process of collectivisation had made considerable progress and thus the role of the cooperatives was accentuated in the new code. Formally, they were placed among the newly introduced socialist organisations. Apart from the agriculture sector, they played a major role, especially in housing.

CC1964 contained very detailed regulation of the use of apartments and land and at the same time introduced a new institution of cooperative apartments (družstevni byty). The very detailed treatment of the legal relationships among the members of apartment cooperatives reflected the newly emerging phenomena of collective use of apartment buildings. The legal regulation of the use of apartments and apartment cooperatives exceeded the measure of detail of any

13 The Czechoslovak Constitution of 1948, art. 157.

14 Knapp, V., Vlastnictví v naší společnosti, "Právník” 1949, No. 7-8, p. 308. 
other institution contained in CC1964. While the traditional institutions of possession or prescription, reintroduced after the amendment of 1982, were treated in one single article, housing was treated in 69 articles in the code. Likewise, after the amendment of CC1964 in 1982, servitudes were treated in two articles and the regulation of housing became even more detailed. One of the first things that can be observed in CC1964 is, therefore, the significant disproportion in the regulation of various civil law institutions. This, however, demonstrated the level of importance considered by the authors of the communist Civil Code regarding various social topics. The priorities in treating civil law institutions were expressed in accordance with the legislative strategy of the Communist Party.

\section{Personal ownership}

Personal ownership (osobni vlastnictvi) under CC1950 does not pertain directly to the category of socialist ownership. ${ }^{15}$ Also, CC1964 does not explicitly mention personal ownership as a socialist type of ownership. Nevertheless, both codes recognised the socialist character of personal ownership and placed it in contrast to private ownership (soukromé vlastnictví, see below).

Personal ownership was, along with non-socialist private ownership, a form of individual ownership recognised by the communist legislation and jurisprudence. Both forms of individual ownership were tolerated side by side with socialist ownership, which was the only form of ownership to really meet the ideological standards set by the communist regime. Although personal ownership was in substance contrary to communist principles refusing the individualistic character of the law, it was accepted by the communist legislation. The incorporation of personal ownership into civil law was, therefore, accompanied by a strict limitation of the property capable of becoming an object of this form of ownership.

The new legal concept of ownership constructed by the communist ideologists never went so far as to limit the ownership of consumer goods. Consumer products along with personal things were the only possible objects of personal ownership. All other things (except for some immovables) were allowed to be only in the socialist ownership belonging to all the citizens. ${ }^{16}$

15 Bělovský, P. Instituty..., pp. 356-360.

16 Plank, K. Osobné vlastnictvo, "Právny obzor" 1952, p. 418. 
In the beginning of the 1950s, personal ownership, just as with socialist ownership, was only starting to function in terms of the constitution of 1948 as well as in terms of the plans of the Communist Party. Accordingly, CC1950 presented only a brief description of personal ownership. ${ }^{17}$ The further text of the code does not explicitly distinguish between personal ownership and private ownership. This flaw, which made it difficult to determine the exact limits of personal ownership, was, however, subject to severe criticism in the official law journals of that time.

The group of things that could become an object of personal ownership and thus personal property was strictly limited. Personal ownership was primarily restricted to personal things, consumer products, and personal savings. It was thus the character of the thing that determined the character of ownership. This meant that if the consumer product turned into a means of production, the character of ownership of the thing changed accordingly.

In comparison to the later development of civil law in the 1960s, the regulation of personal ownership established by CC1950 was considerably more liberal. Unlike CC1964, the first socialist Civil Code allowed the personal ownership of land. The personal ownership of land was in CC1964 replaced with 'the personal use of land'. Both codes, however, allowed also the personal ownership of 'family houses'.

A family house in the socialist civil law became a technical term. CC1950 introduced it as one of the possible objects of personal property. The economic character of this kind of object and its placement among the things excluded from socialist property raised many legal questions. This resulted later in the significantly more detailed treatment of the family house as an object of personal ownership in the Civil Code of 1964. The individual ownership of things whose price would exceed the value of consumer products was seen as something that could threaten the socialist environment. Yet, since it was absurd even for communist jurisprudence to consider a family house property belonging to the whole society, it was therefore accepted to consider it again personal property.

In contrast to the previous Code of 1950, however, the authors of CC1964 decided to present a definition of a family house: 'The family house is a residential building in which at least two-thirds of the floor surface is used for living space. The number of rooms in the family house cannot exceed five, not includ-

17 CC1950, art. 105. 
ing the kitchen. This number can be greater only if the total area of the floor surface of the building does not exceed 120 square metres'. ${ }^{18}$

The personal ownership of family houses was limited not only by the area of the building but by quantity. Art. 129 of CC1964 fixed the number of family houses allowed to be owned by a person to one single house.

The personal ownership of land was allowed only by CC1950. This fact, however, was not explicitly stated by the text of the code but had to be traced by legal interpretation. CC1964, which was to provide a transition to communism, excluded land from personal ownership and made it an object of socialist property only. The persons were nevertheless even under CC1964 allowed to use land for their personal benefit. From the legal point of view, however, the persons were entitled to do this not by ownership of land but by a newly introduced instrument named 'the personal use of land' (osobni uživání pozemku). ${ }^{19}$

Although personal use was introduced as an innovation of CC1964, it had its roots already in CC1950, which came up with an instrument called 'the permanent use' (trvalé uživáni). ${ }^{20}$ The permanent use of land was to be constituted in favour of socialist legal persons. The lack of any further treatment of this institution by CC1950 made it, however, unclear in its contents. Only art. 158 of CC1950 states that socialist legal persons do not need any consent to construct a building on land in permanent use.

CC1964 followed the treatment of personal ownership in the sense of the communist constitution of 1960, which was supposed to provide the legal basis for life in the new communist society. As a consequence, the treatment of personal ownership by CC1964 became more detailed, on the one hand, and more restrictive as to the objects capable of being in personal ownership, on the other. While CC1950 treats personal ownership (and personal property) in one single article, CC1964 devoted to this type of ownership one whole chapter containing ten articles. In CC1964, personal ownership was mentioned already in the preamble to the code as an important means of meeting the demands of the citizens. The same characteristic is given once again further in the text of the code, which demonstrates the ideological purpose of the statement. The legislative commentary to CC1964 defines personal ownership by three main attributes: 1. the indi-

\footnotetext{
18 CC1964, art. 128.

19 Fábry, V., Osobní uživání půdy, "Právnické štúdie” 1964, No. 2.

20 CC1950, art. 103.
} 
visible connection to socialist ownership, 2. the honesty of the source of personal ownership, 3 . the consumer character. ${ }^{21}$

Concerning immovables, CC1964 introduced a radically new perspective towards the disposal of land. If CC1950 implicitly allowed the personal ownership of land (i.e., construction and agricultural land), then CC1964 completely restricted the ownership of any land. This was in accordance with the officially proclaimed ideological statements of the Communist Party because land was considered a means of production. Although CC1964 did not again exclude land from personal ownership explicitly, the text regarding the disposal of land implies that land can be an object exclusively of socialist ownership. Just as with family houses, personal ownership of land was replaced with the newly introduced institution of 'the personal use of land' (derived from the already mentioned 'permanent use of land'). The word 'land' in this case regarded only construction land; the personal use of agricultural land was not possible and could be, therefore, an object of socialist ownership only.

The ban on the personal ownership of land was related to the main ideological proclamation in the preamble to CC1964: 'the land belongs to those who work on it', mentioned already in the constitution of 1948. In practice, this meant that the land belongs to the working class as a whole and cannot be an object of individual ownership. ${ }^{22}$

The objective of the ban on the personal ownership of land and its replacement with the more restrictive 'personal use' was to provide control over the disposal of land. According to the new legal concept of ownership introduced by CC1964, socialist property formally belonged to all people. In practice, however, the administration of it was carried out by state officials. This provided an easier position in the realisation of state-directed construction projects (roads, parking lots, etc.). The state authorities did not have to communicate with the owners of the relevant land in order to expropriate the property.

Personal use was not provided to individuals free of charge and the fee was determined by state legislation. The distribution of land for personal use was performed by the state administration. The land ascribed for personal use remained in socialist ownership (administered again by the state) and, therefore, could not be transferred by the person entitled to it for personal use. On the other hand, the

${ }^{21}$ Knapp, V. and Plank, K. et al., Učebnice československého občanského práva, Praha 1965, vol. II., p. 26.

22 Eliáš, K., Právo osobního uživání pozemku, "Socialistická zákonnost” 1983, p. 242. 
institution of personal use bore certain signs of the iura in rem which brought it very close to regular ownership. The duration of personal use was not limited by the life of the entitled person but succeeded to his/her heirs. Also, the protection of personal use was very similar to the protection of personal ownership.

CC1964 proclaimed that the protection of personal ownership is provided only to those owners who acquired it from an honest source. ${ }^{23}$ This meant that the acquirer's knowledge of the quality of the source was irrelevant. In case a person acquired it in good faith yet from a thief, possession acquired this way was not entitled to protection since the source was not honest. The socialist organisations were assumed to be always an honest source.

\section{Private ownership}

Private ownership (soukromé vlastnictvi) was regarded by the communist doctrine as a relic of capitalism that was to be temporarily tolerated and accepted within the communist legal system. ${ }^{24}$ This is why unlike personal ownership, private ownership was not seen as an institution of the socialist law system. On the other hand, just as with personal ownership, private ownership was also a form of individual ownership, which was recognised by the law as a regulated alternative to the socialist common ownership.

In 1950, when CC1950 was promulgated, the process of collectivisation and nationalisation had only commenced. Even though the war had inflicted severe damage to the property of most of the people, still many of them owned a significant amount of property (land, cattle, buildings, personal savings, etc.). This was considered by the growing Communist Party as a remnant of the bourgeois society.

The contents of the Civil Code, therefore, had to reflect this situation despite the political or ideological objectives. Private property was declared a temporary phenomenon, tolerated by the communist legislation until the transformation process was finished. ${ }^{25}$ The socialist environment and society were expected to spontaneously eliminate the needs of the citizens for private ownership since all their demands were to be furnished by the socialist property and by the socialist organisations. The Communist Party had to face the fact that in the beginning of the $1950 \mathrm{~s}$, the citizens were not yet prepared to reject the traditional individual

23 CC1964, art. 125.

24 Bělovský, P., Instituty..., pp. 360-362.

${ }_{25}$ Knapp, V., Hlavni zásady československého socialistického občanského práva, Praha 1958, p. 358. 
forms of ownership. The transformation into socialism and subsequently into communism had to be regarded as a gradual process. Personal ownership was to slowly replace private ownership, which would consequently be followed by the elimination of all individual property in the communist society. ${ }^{26}$

The contents of CC1950 reflects the situation faced by the Communist Party. Private ownership was, therefore, not made inferior to the socialist personal ownership. It was quite the contrary. Many of the civil law principles regarding personal ownership were equally applicable to private ownership (as the acquisition of ownership, the common ownership, the protection of ownership). The distinction between the various types of ownership established by the constitution of 1948 was nevertheless subsequently not treated clearly and accurately by CC1950. This resulted, on the one hand, in much legal confusion and many conflicts. On the other hand, this proved that the motivation for drawing a strict line between socialist and non-socialist ownership was not as strong as could be expected.

The process of nationalisation was an inseparable part of the communist planned transformation of Czechoslovak society. It was, however, started even before the constitution of the communist government in 1948. Based on decrees by the president, n.100-103/1945, some companies in light and heavy industry were nationalised already in 1945 . These were followed in the same year by insurance companies and banks. In 1948, general nationalisation had hit all companies with a number of employees exceeding 50 . The process subsequently affected all construction companies, travel agencies, and spa companies. The gradual process of nationalisation of the Czechoslovak industry was in 1947 and 1948 finalised by large-scale land reform.

Business undertakings were allowed by the constitution of 1948, which declared in its art. 151 that: 'a business undertaking is either public (performed by the state), cooperative or private'. As for a private business undertaking, the constitution explicitly tolerates the existence of companies and enterprises with a number of employees not exceeding 50. Accordingly, the declaration of the constitution in 1948 was reflected by CC1950. The legislative commentary nevertheless states that exploitation is still a common phenomenon represented by 'rural rich men' (the so-called 'kulaks'). It is, therefore, only a matter of time and agricultural strategy before they are eliminated, adds the legislative commentary.

26 Kratochvíl, Z., Předmět a systém socialistického práva občanského, "Právník" 1962, No. 1, p. 32; Č́žkovská, V. Osobni vlastnictví a jeho úprava v evropských socialistických právních rádech, "Acta Universitatis Carolinae - Iuridica" 1974, No. 3, p. 178. 
For the purpose of farming and private agricultural activities, CC1950 allowed the private ownership of agricultural land. This was nevertheless allowed only in the limits set by the constitution of 1948, which restricted the private ownership of agricultural land to 50 acres. The recognition of minor farming was in its roots inspired by the same source, which affected the whole concept of the Czechoslovak Civil Code of 1950, from the Soviet civil law. In practice, however, all private business or farming activities were unwelcome, and, therefore, rather tolerated then supported.

With the introduction of CC1964, the approach of the state legislator towards private property, as well as towards all private activities of people, drifted and became more conservative. Still, even in the beginning of 1960, neither state legislation nor the official ideology managed to eliminate all undertakings. For this reason, CC1964 had to again contain the treatment of private ownership. This is, however, understood as the result of a political compromise. Despite the economic crisis at the end of 1950, President Novotný officially declared in 1958 that the construction of a socialist society had finished and that all the preconditions necessary for the process that would lead the society into communism were fulfilled. Communism was officially expected to be reached in the beginning of the 1980s. Instead of liberalising the society, which would prevent the further deterioration of the economy, the state legislator decided to reinforce the mechanisms securing the socialist regime. The consequence of this approach can be seen in the contents of CC1964, as described above.

The proclamation of President Novotný, which ignored all economic indicators and blindly followed the ideological plans of the Communist Party, resulted in the slow deterioration of the economy and consequently, the living standards of the people. From the present perspective, this proclamation can be viewed as one of the elements that contributed to the formation of the dissident movement and later to the democratic revolution in 1989.

\section{Literature}

Barnovský, M., K niektorým otázkam spoločenského vývoja Československa v šedesiatych rokoch, "Dějiny socialistického Československa" 1989, No. 10.

Bělovský, P., Instituty občanského práva 1950-1982, in: Kuklík, J. (ed.), Dějiny československého práva 1945-1989, Praha 2011.

Bělovský P., Občanské právo, in: Bobek, M., Molek, P., and Šimíček, V., Komunistické právo v Československu: Kapitoly z dějin bezpráví, Brno 2009. 
Bosiacki A., Roman Law in Totalitarian Systems: Soviet Union, Italy and Germany Case Study, in: Au delà frontières, melanges de droit Romain offert à Witold Wolodkiewicz, Warszawa 2000, vol. 1.

Čížkovská, V., Osobní vlastnictví a jeho úprava v evropských socialistických právních ř́dech, "Acta Universitatis Carolinae - Iuridica" 1974, No. 3.

Dvonč F., and Štěpina J., Návrh nového občanského zákonnika - zákonníka socialistickej spoločnosti, "Právny obzor" 1963, No. 3.

Eliáš K., Právo osobního užívání pozemku. “Socialistická zákonnost” 1983.

Fábry V., Osobní užívání půdy, "Právnické štúdie” 1964, No. 2.

Karass, A. V., Obsah práva státního socialistického vlastnictví. "Sovětskoje gosudarstvo i pravo" 1949, No. 7.

Khruschev N. S., Moskovskaia Pravda, April 2nd, 1960.

Knapp V., Hlavní zásady československého socialistického občanského práva, Praha 1958.

Knapp V., Operativní správa národního majetku národnimi podniky, in: V. Knapp, K., Petržalka, Z. Isaakovič Škundin, K otázkám nového občanského práva, Praha 1950.

Knapp V., Vlastnictví v naši společnosti, "Právník” 1949, No. 7-8.

Knapp V., Vlastnictví v lidové demokracii, Praha 1952.

Knapp V., and Plank K. et al., Učebnice československého občanského práva, Praha 1965, vol. II.

Kratochvíl Z., Předmět a systém socialistického práva občanského, "Právník” 1962, No. 1.

Plank, K., Osobné vlastnictvo, "Právny obzor" 1952.

Venědiktov, A.V., Státní socialistické vlastnictví, Praha 1950.

\section{Legislation}

Amendment of law no. 40/1964 (Civil code) (novela občanského zákoníka), no.131/1982 Coll.

Civil code of Czechoslovakia (občanský zákoník), no. 141/1950 Coll. (full text see https:// www.psp.cz/sqw/sbirka.sqw?cz=141\&r=1950).

Civil code of Czechoslovakia (občanský zákoník), no. 40/1964 Coll. (full text see https:// www.psp.cz/sqw/sbirka.sqw?cz=40\&r=1964).

Constitution of the Czechoslovak republic (Ústava Československé republiky), no. 150/1948 Coll. (full text see https://www.psp.cz/docs/texts/constitution_1948.html).

Decrees of the President of Czechoslovak republic (Dekrety prezidenta republiky), no.100-103/1945 Coll. 